\title{
Niccolò Machiavelli: Father of Modern Constitutionalism
}

\author{
Mortimer N.S. Sellers \\ University of Baltimore School of Law, msellers@ubalt.edu
}

Follow this and additional works at: http://scholarworks.law.ubalt.edu/all_fac

Part of the Constitutional Law Commons, and the Legal History Commons

\section{Recommended Citation}

Niccolò Machiavelli: Father of Modern Constitutionalism, 28 Ratio Juris 216 (2015). 


\title{
Niccolò Machiavelli: Father of Modern Constitutionalism
}

\author{
MORTIMER N. S. SELLERS
}

Abstract. Niccolò Machiavelli is the father of modern constitutionalism. Constitutionalism began anew in the modern world with the study of the ancient republics and it was Machiavelli who inaugurated this revived science of politics. Five hundred years after the composition of Il Principe and the Discorsi we are still working out the implications of applying reason to the structures of law and government in pursuit of justice and the common good. Modern constitutionalism and ancient republicanism share three central beliefs: first, that government should serve justice and the common good; second, that government should do so through known and stable laws; third, that these will best be secured through the checks and balances of a well-designed constitution. Machiavelli took the theories and experiences of republican Rome and applied them to his own era. This application of reason to constitutional design transformed the politics of emergent modernity and reconfigured government throughout the world.

\section{Introduction}

Five hundred years ago, Niccolò Machiavelli completed Il Principe, his famous manual for princes (Machiavelli 1513). Some consider this event to have been the beginning of modern political science, which may well be true. But Machiavelli's greater importance arises from his Discorsi sopra la prima deca di Tito Livio (Machiavelli 1531), which he wrote at about the same time. Less discussed today than Il Principe, the Discorsi have had a deeper and more lasting influence. The Discorsi were more unusual, more revolutionary, and more transformative than $\mathrm{Il}$ Principe when they were written and have left a more significant legacy. Through them Machiavelli became the father of modern constitutionalism. He revived the legacy of ancient republican theory, transformed the politics of emergent modernity and reconfigured government in the modern world. Machiavelli changed the direction of political discourse and all his most important successors have acknowledged the priority of his ideas.

Machiavelli's position as the father of modern constitutionalism has three main aspects: paternity, modernity, and constitutionalism, each of which requires definition and each of which deserves further examination. "Father" here signifies that Machiavelli was originator and nurturer of the constitutionalist tradition (Sellers 1998). "Modernity" signifies the project of replacing authority with reason, which 
inaugurated the modern world (Sellers 2009). "Constitutionalism" is the struggle to construct the best form of government for any given society, which is to say in Machiavelli's case, primarily for Florence (Sellers 2014). The central focus of this discussion will be constitutionalism, and Machiavelli's innovation, but modernity is also centrally important. Modern constitutionalism begins in any society when statesmen apply their reason to the structure of the state to secure better government and laws. Machiavelli revived the project of political reason in Florence, by returning to the constitutional tradition of republican Rome.

This raises the relationship between "republicanism" and "constitutionalism" and more specifically the extent to which the ancient conception of republicanism led to contemporary theories of constitutional government. There is a direct connection. Contemporary theories of constitutional government arise almost entirely from ancient republican ideas. They are an extension of the same effort. Modern constitutionalism is simply a revival and continuation of the ancient republican tradition under another name. Niccolò Machiavelli was the most important author of this revival and is therefore the father of modern constitutionalism. Machiavelli rediscovered constitutionalism and the science of republican politics after a millennium of tyranny and oppression.

\section{Constitutionalism}

What then is the project of constitutionalism that Machiavelli revived for the modern world? Constitutionalism is the project of designing the fundamental structure of government so that it will serve justice and rule well. Machiavelli set out to do so, above all in his Discorsi sopra la prima deca di Tito Livio (cf. Livius 1974). Machiavelli sought systematically to study the examples both of antiquity and of modern politics to better constitute the republic and improve the structure of the state. He claimed as his first aim the common benefit or "commune benefizio" of all those subject to the republic (Machiavelli 1531, I.proemioA.1). This was and is (as it should be) widely recognized in his time as in ours as the primary purpose and justification of government. Machiavelli explained that in seeking political institutions for the common good he would apply to politics and the constitution a technique already well known in the other arts and sciences. Machiavelli sought to apply his own reason to ancient knowledge and experience to learn how best to constitute republics, just as contemporary Italian sculptors copied ancient statues, or architects studied Vitruvius, to create more beautiful and well-constructed works of art.

This then was to be the constitutionalist technique. As lawyers studied Roman civil law, and doctors studied Galen, so Machiavelli set out to draw practical lessons from the study of history to regain the liberty and virtue of the ancients. Machiavelli claimed this approach as an innovation and insisted that he was making a vital improvement to Italian politics. He claimed to be the first modern politician to apply reason to history to learn the lessons of good government. This was indeed a new thing in his era, and new in the modern world. As in all other areas of knowledge, the knowledge of politics had been at a standstill, even in regression, since the decline of Rome. To surpass the ancients in any field, the moderns had first to understand them. Machiavelli turned his modern contemporaries to ancient knowledge and experience as the first step in applying reason to 
politics, as to any other field. To advance any science, one must begin with reason and reality. Machiavelli found both in the ancient world.

Constitutionalism shares with ancient republicanism a theory of the purpose of government (to serve justice and the common good), a vision of the method for doing so (through known and stable laws), and a technique for securing success (through the checks and balances of well-designed constitutional architecture). Machiavelli took both the theories and the experience of republican Rome and applied them to the political difficulties facing Florence, Italy, and Europe in his own era. How can a polity ever secure government for the common good in the midst of such violence, avarice, ambition, corruption, superstition and misplaced power as existed in Europe when Machiavelli wrote Il Principe and his Discorsi? Machiavelli suggested that checks and balances between different powers in government could secure better results than unchecked power in the hands of any individual or faction or party. He proposed the election of public officials and respect for the rule of law. And he supported these proposals by citing the experience of republican Rome.

\section{Paternity}

Machiavelli thought that he was doing something new and important by reviving republican politics for the modern world, but to be the metaphorical father of an intellectual tradition one must have metaphorical children and they must acknowledge one's paternity to their ideas. The decisive evidence for Machiavelli's influence is the testimony of his successors, proven in its sincerity by their frequent disapproval of the man himself. All the great heroes of modern constitutionalism acknowledged Machiavelli as their intellectual father and inspiration, even as they quarreled with his character and conclusions and tried to improve on his insights.

The English Revolution, the American Revolution, the French Revolution, and the whole modern impetus for constitutional reform began with the Machiavelli's Discorsi. James Harrington in England (Harrington 1977), John Adams in America (Adams 1787-1788), and the baron de Montesquieu (Montesquieu 1748) and Jean-Jacques Rousseau (Rousseau 1762) in France, all expanded on the writings of Machiavelli, but also on the ancient authors on whom he too had relied: Cicero (Cicero 1913, 1928), Polybius (Polybius 1922), Sallust (Sallustius 1931), Tacitus (Tacitus 1906, 1911), Plutarch (Plutarchus 1949-1971), Plato (Plato 1902), Aristotle (Aristoteles 1957) and of course Livy (Livius 1919), as in the Discorsi. They viewed themselves as part of the same tradition that Machiavelli had revived with his discussions of Livy and of Rome.

The next great triumph of constitutionalism and constitutional thought after Machiavelli's Florence was in the English battle against the Stuart monarchs, culminating in the Glorious Revolution of 1688. James Harrington, who proposed a new constitution of liberty for England in his Oceana, cited Machiavelli as "the only politician" (meaning the only student of political science) since antiquity. Harrington praised Machiavelli for retrieving what he called "the ancient prudence" and "the empire of laws and not of men" (Harrington 1977, 8-10). When Americans sought to establish constitutional government a century later, they too turned to Machiavelli, and his sources, and those who followed in his tradition. John Adams, the principal constitutional theorist of the American Revolution, 
praised Machiavelli as "the first who revived the ancient politics" for the modern world. In this he also followed the French philosophes. Adams observed that Montesquieu "borrowed the best part of his book from Machiavel, without acknowledging the quotations," and that "Milton, Harrington, and Sidney, were intimately acquainted with the ancients and with Machiavel" (Adams 1787-1788 I.325. Cf. Harrington 1977; Milton 1991; Sidney 1698).

\section{Modernity}

Modernity signifies the project of replacing authority with reason. This attitude came to Europe at different times in different disciplines between the twelfth and the sixteenth centuries, but in the case of politics and constitutionalism it was with the writings of Machiavelli, as he attempted to reform the Florentine state. Of course "modernity" in its simplest sense simply indicates whatever is most recent, and this can cause confusion. There was a time when "modern" signified the Christian era, in opposition to the "antiquity" that preceded it. Only later did "modernity" come to be associated with the new age of renaissance and enlightenment (Sellers 2009, 247). Machiavelli and Harrington wrote in opposition to the tyranny and anarchy of their own age, and recurred to the example of Rome for the courage to challenge existing institutions. Rome's republican constitutionalism was the "ancient prudence" that they sought to revive. "Modern prudence" (in this earlier vocabulary) was still the lawless politics of contemporary Europe-the politics that Machiavelli and his successors so fervently hoped to replace.

Modern constitutionalism at its core was simply a revival of the ancient republican tradition. James Harrington divided the whole history of government into two great epochs: the first, "ending with the liberty of Rome," he called the "ancient prudence" or government "de jure" — defined as "the art whereby a civil society of men is instituted and preserved upon the foundation of common right or interest." Harrington praised Livy and Aristotle for advocating the ancient prudence and advancing what he called the "empire of laws and not of men," which is to say "constitutional government" or "constitutionalism," in our own more modern vocabulary. The other kind of government began, Harrington said, "with the arms of Caesar" which "extinguishing liberty" created what was in Harrington's day still called the "modern prudence" or government "de facto," that had "deformed the whole face of the world with those ill features of government" ... "whereby some man, or some few men, subject a city or a nation, according unto his or their private interest." This is "the empire of men and not of laws," because the rulers are able to make and interpret the laws for their own benefit alone (Harrington 1977, 8).

Harrington's government "de jure" is what we would now call "constitutionalism" - and he attributed his insights on this point and on the "ancient prudence" to Niccolò Machiavelli. Harrington contrasted Machiavelli with Thomas Hobbes, the great champion of the "modern prudence" or government de facto, where rulers face no constitutional constraint (Harrington 1977, 13). In doing so, Harrington acknowledged Machiavelli as the father of modern constitutionalism. He praised Machiavelli as the first modern student of political society and government for the common good. His primary source for this was the Discorsi sopra la prima Deca di Tito Livio. The Discorsi, which talk so much about antiquity, are nevertheless in many ways a much more modern document than Il Principe, which 
touches more on contemporary affairs. Il Principe, a short handbook of tactics for princes, enlivened a well-worn template with remarkable frankness and insight, but the Discorsi challenged the very basis of the state. The Discorsi consider not only what would be the ideal frame of government in various cultures and circumstances, but also the deeper and more difficult question how to get from the violent and corrupt politics of Italy and Europe as they actually existed to a better world of liberty, justice and government for the common good.

\section{English Constitutionalism}

Britain produced the first great triumph of modern constitutional debate, when commonwealthsmen waged the English Civil War (at least in their writings) as a fight for mixed and balanced constitutional government against tyranny and oppression. But although the English subjected their king to law and the constitution in 1649, they never achieved a stable settlement. This began the march towards constitutional liberty in Europe, that saw real and lasting results with the Glorious Revolution of 1688. James Harrington, the most sophisticated constitutionalist of this era, grouped Machiavelli with the ancients as "the only politician of later ages." He saw Machiavelli as the first modern advocate of government by reason, seeking to secure the common good with checks and balances in the constitution. As Harrington explained it, magistrates and the executive power should be balanced by an independent senate, balanced in turn by a larger popular assembly, to create a tripartite architecture of governmental power, serving the welfare of the sovereign people. Harrington wrote that there could be "no other commonwealth but this in art or nature, and so it is no wonder if Machiavel had shown us that the ancients held this only to be good" (Harrington 1977, 25).

While it was the kings themselves who precipitated the English revolutions with their tyranny, Machiavelli and the republican sources that he reintroduced into political discourse furnished models and a vocabulary for the new constitutional institutions that would replace the kings' arbitrary power. Harrington acknowledged his debt to Machiavelli. He honored Machiavelli as "the sole retriever of this ancient prudence" (Harrington 1977, 30). He thanked Machiavelli for reviving the insight of Aristotle "che la multitudine è più savia e più costante che un principe" (Machiavelli 1531, I.58.1). Machiavelli knew that the people, if shown the truth, will follow it-which is why he favored more democratic Rome over the cultured oligarchy that prevailed in Venice and in many other Italian states.

The English republicans and commonwealthsmen found their orders of government in Machiavelli and in his ancient models: Aristotle, Livy, Cicero, and Polybius. The new constitutionalism followed Machiavelli in mining Roman and Greek history for experimental evidence of different frames of government in practice. The primary emphasis was not so much on Machiavelli's conclusions as it was on his technique. Harrington, Milton, Sidney and the rest compared Rome to Sparta, Athens, and Venice, in trying to determine which institutions would be most effective in securing justice and the common good for all citizens, and forestalling the tyranny of monarchy in England. Italian experiments in constitutional design had not been a striking success. England offered the first example of successful constitutional government in the modern world. The checks and balances of 
English constitutionalism, their rule of law ideology, and the doctrines of popular sovereignty and mixed government that they embraced all had their origins in Machiavelli and in republican Rome.

\section{American Constitutionalism}

The next great constitutional success after Great Britain was in America, beginning with the state constitutions after 1776, then the Federal Constitution of 1787, made real in 1790. Here too, as in Britain, Machiavelli played a significant role, along with his English and French commentators and the ancient republican models he himself had read and discussed. John Adams' Thoughts on Government (Adams 2000), which inspired the state constitutions, and his Defense of the Constitutions of Government of the United States of America (Adams 1787-1788), which informed the federal constitution, both followed the Machiavellian model of popular sovereignty, mixed government, and the rule of law, as did the Massachusetts constitution of 1780, of which Adams was the principal draftsman. John Adams praised Machiavelli for his realism and for realizing that "whoever would found a state, and make proper laws for the government of it, must presume that all men are bad by nature, and that they will not fail to show that natural depravity of heart, whenever they have a fair opportunity." Adams noted that Montesquieu also knew and "constant experience shows us that every man invested with power is apt to abuse it: he pushes on until he finds something that limits him." So "to prevent the abuse of power, it is necessary, that by the very disposition of things, power should be a check to power" (Adams 1787-1788, I.131). This is the essence of constitutionalism and the primary lesson that Montesquieu and Adams and the Americans took from Machiavelli and from his models Cicero, Livy, Polybius, and the rest.

Adams quoted Machiavelli at length to substantiate the observation that "men are never good but through necessity: on the contrary, when good and evil are left to their choice, they will not fail to throw everything into disorder and confusion." Therefore, although "hunger and poverty may make men industrious [...] laws only can make them good" (Adams 1787-1788, I.133-4). He devoted an entire chapter of his Defence to Machiavelli's conception of "mixed government," which divided governmental powers in such a way that each branch would be a check upon the others. Machiavelli praised Lycurgus for having done this effectively in Sparta and criticised Solon for failing to do so in Athens. But above all Machiavelli held up republican Rome as the ideal constitutional model and Adams repeated his observation. Rome reached "the highest degree of perfection that any commonwealth is capable of attaining to" (Adams 1787-1788, I.147).

\section{Republicanism}

The ideology of constitutionalism did not yet have currency under that name when Harrington, Sidney, Montesquieu, and Adams wrote their models for constitutional government, so they spoke instead of "republics," and republicanism was the project that they followed Machiavelli in hoping to revive. "Republicanism" in its simplest form is no more than government for the common good, but republicans beginning with Aristotle and Cicero had always understood that there can be no republic without the rule of law, and no rule of law without the "republican form 
of government," with all that entails. The "great question," as Adams put it, was "what combination of powers in society, or what form of government, will compel the formation of good and equal laws, an impartial execution, and faithful interpretation of them, so that the citizens may constantly enjoy the benefit of them, and be sure of their continuance" (Adams 1787-1788, I.128). Machiavelli's great virtue in the eyes of the first constitutionalists was that he revived this inquiry and put it on a scientific basis.

"The arts and sciences in general," John Adams wrote in 1787, "have had a regular course of progressive improvement" in recent years, so that "the inventions in mechanic arts, the discoveries of natural philosophy, navigation, and commerce" and "the advancement of civilization and humanity" have "occasioned changes in the condition of the world and the human character which would have astonished the most refined nations of antiquity." Adams went on to observe that the "checks and balances of republican governments have been in some degree adopted by the courts of princes." And yet, Adams observed, "the knowledge of the principles and construction of free governments," knowledge in which "the happiness of life, and even the further progress of improvement in education and society, in knowledge and virtue, are so deeply interested," has remained "at a full stand still for two or three thousand years" (Adams 1787-1788, I.i). The great virtue of Machiavelli in the eyes of Harrington, Adams, Montesquieu, and the rest, was that he revived the science of "free government," the government of laws, and government for the common good. They read and quoted Machiavelli because he understood and acted on his understanding that the construction of constitutions and laws is a science accessible to reason, like all the others.

John Adams and the other founders of modern constitutionalism understood government to be a science like all the others, only vastly more important. Just as architects consult Vitruvius before building, so statesmen (Adams said) should consult Machiavelli, and also Cicero, Livy and Polybius, as Machiavelli himself had done. The new republicans did not slavishly copy or only repeat Machiavelli's prescriptions for republican government, although they often did so, but rather engaged him and the others in a dialogue, based on reason and experience, in order to challenge and improve his findings. Modern constitutionalist ideas arose from ancient republicanism and Machiavelli was the one who did the most to revive this tradition of constitutional inquiry in Europe, or at least was given credit for having done so by those who did the most to build upon his theories and even sometimes to implement them in practice.

\section{Machiavelli's Constitutionalism}

Having examined the depth of his influence, we should briefly consider what Machiavelli's main points actually were as they relate to politics and the ideal constitution-and which of these points made the greatest impression on his readers and on the emergence of constitutional thought. First, in the Discorsi, Machiavelli set out to study the example of antiquity and above all of Rome, as recorded by Livius (1974). Second, his purpose in doing so was to draw practical lessons from the experience of the Romans. Machiavelli observed that states must have power if they are to survive, but if they are to be free and have justice, they must make laws for the common good, which requires a constitutional mixture and 
balance of the aristocratic, monarchic, and democratic aspects of government to create a "republica perfetta," like the one that existed at Rome (Machiavelli 1531, I.2.30).

Machiavelli identified the secret of Rome's freedom and power as the balance between the plebs and the senate. What made the republic both free and powerful ("libera e potente") was the constant conflict between the nobles and the people (Machiavelli 1531, I.3.1). Machiavelli favored the ultimate sovereignty of the people for two reasons. First, because their liberty makes them willing to fight for the republic against its enemies; and second, because Machiavelli believed-following Cicero-that the people collectively judge well, when statesmen lay the truth before them. So liberty is ultimately safest in the hands of the people and not the "great men" ("grandi"), who contest for power among themselves.

The saddest part of Machiavelli's work was his chastened conviction that republican government will be impossible to create in states that have become corrupt. The only route out of this impasse would be perhaps to find a good man willing to use bad methods to achieve the necessary reform. Yet this can never happen, when the people are as corrupt as Machiavelli believed them to be in Italy, France and Spain. Machiavelli condemned Italy as corrupt above all other lands and the source of a spreading corruption that debased the whole world, so that Florence, for example, in its whole history, had never really been a republic, because it was so dishonest. Machiavelli perceived and sadly recorded that Florence had never enjoyed good government, because Florence never had institutions designed primarily to secure the common good of the people, which is the essence of republican government (Machiavelli 1531, I.18). Republican government is government that serves the res publica, and not some private interest or faction.

\section{The Science of Politics}

Machiavelli understood that "in all cities and in all peoples there are the same desires and the same passions as there ever were" (Machiavelli 1531, I.39.1). This makes the science of politics possible. And yet, Machiavelli also saw or believed that he saw that where equality among citizens does not exist, the people will become corrupt and it will be impossible to establish a republic. This was the situation in Italy. Little wonder, then, that Machiavelli retired to his study, as he told his friend Francesco Vettori, and put on his curial robes, and entered into discourse with ancient men, so that they could nourish him and educate him and teach him to love reason and science and humanity in the midst of a world that was entirely dishonest. This was his frame of mind when he wrote his pamphlet de principatibus, to grapple with the world as it actually was, and not as it ought to be.

Today's constitutionalists, and the learned scholars of the International Association of Constitutional Law, are like Machiavelli. We have put on our curial robes, we have conversed with the ancients, and we have retired to our study in San Andrea Percussina. Most of us have no hope of real political power or even of influence. We have no voice in the counsels of the powerful and the world around us is entirely corrupt. Will we have the courage, even so, to follow the example of Machiavelli? Machiavelli set us a valuable example in the two great disciplines of 
which he is the modern founder-constitutionalism and political science. Constitutionalism is the priceless contribution of the Discorsi. Il Principe is a masterpiece of political science.

Machiavelli in his Discorsi examined the best orders of politics, the best structures of government, of law, liberty, and the common good, based above all on experience, and particularly the experience of Rome. Machiavelli set out in the Discorsi to understand the constitution of liberty in a republic or a free state. He looked in Il Principe more to the world in which he actually lived, and how a prince could control and regulate the state in a polity incapable of republican government. By gaining and maintaining power in the midst of corruption, Machiavelli's prince might perhaps be able to do some good for the world. He might even found a republic.

\section{Conclusion}

Niccolò Machiavelli was the father of modern constitutionalism. Modern constitutionalism began with the study of the ancient republics and it was Machiavelli who inaugurated this new science of politics. Five hundred years after the composition of Il Principe and the Discorsi we are still working out the implications of applying reason to laws and the constitution, in pursuit of justice and the common good. Modern constitutionalism and ancient republicanism share three central beliefs. First, that government should serve justice and the common good. Second, that government should do so through known and stable laws. Third, that these will best be secured through the checks and balances of well-designed constitution. Machiavelli took the theories and experience of republican Rome and applied them to the political difficulties of his own era. This application of reason to government was new to Machiavelli's contemporaries. This was the dawn of new world.

Machiavelli was the father of modern constitutionalism not only in the temporal priority of his writings, but also in his acknowledged influence on those who followed. James Harrington, John Adams, and the baron de Montesquieu all followed Machiavelli directly in the attempt better to understand (in Adams' words) "what combination of powers in society, or what form of government will compel the formation of good and equal laws, an impartial execution, and faithful interpretation of them, so that the citizens may constantly enjoy the benefit of them, and be sure of their continuance" (Adams 1787-1788, I.128). Machiavelli was the "sole retriever" of the "ancient politics" for the modern world. Imperium legum potentiora quam hominum esto!

Center for International and Comparative Law

University of Baltimore

1420 North Charles Street

Baltimore, Maryland 21201, USA

E-mail: mortimer.sellers@gmail.com

\section{References}

Adams, J. 1787-1788. A Defence of the Constitutions of Government of the United States of America. London: Dilly. 
Adams, J. 2000. Thoughts on Government. In J. Adams, The Revolutionary Writings of John Adams. Ed. C. B. Thompson, 287-93. Indianapolis: Liberty Fund. (1st ed. 1776.)

Aristoteles. 1957. Politica. Ed. W. D. Ross. Oxford: Oxford University Press.

Cicero, M. Tullius. 1913. De officiis. Ed. W. Miller. Cambridge, MA: Harvard University Press.

Cicero, M. Tullius. 1928. De re publica et De legibus. Ed. C. W. Keyes. Cambridge, MA: Harvard University Press.

Harrington, J. 1977. The Commonwealth of Oceana. In J. Harrington, The Political Works of James Harrington. Ed. J. G. A. Pocock, 1-266. Cambridge: Cambridge University Press. (1st ed. 1656.)

Livius Patavinus, T. 1919. Ab urbe condita. Libri VI-X. Ed. C. F. Walters and R.S. Conway. Oxford: Oxford University Press.

Livius Patavinus, T. 1974. Ab urbe condita. Libri I-V. Ed. R. M. Ogilvie. Oxford: Oxford University Press.

Machiavelli, N. 1513. Il Principe. (First print edition 1532. Rome: Antonio Blado.)

Machiavelli, N. 1531. Discorsi sopra la prima deca di Tito Livio. Rome: Antonio Blado.

Milton, J. 1991. Political Writings. Ed. M. Dzelzainis. Cambridge: Cambridge University Press.

Montesquieu, C.-L. de Secondat, baron de la Brède et de. 1748. De l'esprit des lois. Geneva: Barillot.

Plato. 1902. Opera. Ed. I. Burnet. Oxford: Oxford University Press.

Plutarchus. 1949-1971. Vitae. Ed. C. Lindskog and K. Ziegler. Leipzig: Teubner.

Polybius. 1922. Historiae. Ed. W. R. Paton. Cambridge, MA: Harvard University Press.

Rousseau, J.-J. 1762. Du contrat social. Amsterdam: Marc Michel Rey.

Sallustius Crispus, G. 1931. Bellum Catilinae et Bellum Iugurthinum. Ed. J. C. Rolfe. Cambridge, MA: Harvard University Press.

Sellers, M. 1998. The Sacred Fire of Liberty: Republicanism, Liberalism, and the Law. Basingstoke: Macmillan.

Sellers, M. 2009. The Influence of Marcus Tullius Cicero on Modern Legal and Political Ideas. Ciceroniana 13: 245-80.

Sellers, M. 2014. What is the Rule of Law and Why Is It so Important? In The Legal Doctrines of the Rule of Law and the Legal State. Ed. R. Silkenat, J. E. Hickey, Jr., and P. D. Barenboim. Dordrecht: Springer.

Sidney, A. 1698. Discourses Concerning Government. London: Booksellers of London and Westminster.

Tacitus, P. Cornelius. 1906. Annalium libri. Ed. C. D. Fisher. Oxford: Oxford University Press.

Tacitus, P. Cornelius. 1911. Historiarum libri. Ed. C. D. Fisher. Oxford: Oxford University Press. 
Copyright of Ratio Juris is the property of Wiley-Blackwell and its content may not be copied or emailed to multiple sites or posted to a listserv without the copyright holder's express written permission. However, users may print, download, or email articles for individual use. 